\title{
Bosmina longirostris (O.F. Müller, 1785) (Anomopoda: Cladocera) in Australia: a new case of the anthropogenic introduction of a boreal waterflea
}

\author{
P.G. Garibian, A.A. Kotov ${ }^{1}$ \\ A.N. Severtsov Institute of Ecology and Evolution of the Russian Academy of Sciences, Leninsky \\ Prospect 33, Moscow 119071, Russia. E-mail: petr.garibyan21@mail.ru \\ ${ }^{1}$ Corresponding author,E-mail: alexey-a-kotov@yandex.ru \\ P.G. Garibian: ORCID: 0000-0003-4505-3133, ResearcherID: R-8434-2018 \\ A.A. Kotov: ORCID: 0000-0002-8863-6438, ResearcherID: B-1549-2010
}

ABSTRACT: It is well-known that some waterflea taxa (Crustacea: Branchiopoda: Cladocera) formed stable populations in non-indigenous territories after their occasional human-mediated introduction. Some cases of such invasions are known for the Australasian region. Below we report on the finding of a population of Bosmina longirostris (O.F. Müller, 1785) (Anomopoda: Bosminidae) in Australia which also has appeared as a result of occasional anthropogenic-mediated introduction. Most probably, B. longirostris was introduced to Australia from a Holarctic locality together with trout which is cultivated in the lake where it was found.

How to site this article: Garibian P.G., Kotov A.A. 2021. Bosmina longirostris (O.F. Müller, 1785) (Anomopoda: Cladocera) in Australia: a new case of the anthropogenic introduction of a boreal waterflea // Invert. Zool. Vol.18. No.3. P.240-246. doi: 10.15298/ invertzool.18.3.04

KEY WORDS: Bosmina, Cladocera, Australia, fauna, biological invasion.

\section{Bosmina longirostris (O.F. Müller, 1785) (Anomopoda: Cladocera) в Австралии: новый случай антропогенной интродукции бореального ветвистоусого ракообразного}

\author{
П.Г. Гарибян, А.А. Котов ${ }^{1}$
}

Институт проблем экологии и эволюичи им. А.Н. Северцуова РАН, Ленинский проспект д. 33, Москва 119071, Россия. E-mail: petr.garibyan21@mail.ru

${ }^{I}$ Автор для переписки, E-mail: alexey-a-kotov@yandex.ru

РЕЗЮМЕ: Широко известно, что некоторые представители ветвистоусых ракообразных (Crustacea: Branchiopoda: Cladocera) сформировали устойчивые популяции на новых территориях после их непреднамеренного занесения человеком. Некоторые подобные случаи известны для Австралазийского региона. Мы приводим сообщение о находке Bosmina longirostris (O.F. Müller, 1785) (Anomopoda: Bosminidae) в

The paper is devoted to 70th anniversary of Prof. V.V. Malakhov.

Статья посвящена 70-летию со дня рождения проф., акад. В.В. Малахова. 
Австралии, которая также появилась там в результате непреднамеренного заноса человеком. Скорее всего, B. longirostris была интродуцирована в Австралию из Голарктики вместе с форелью, разводимой в водоеме, в котором босмина была найдена.

Как цитировать эту статью: Garibian P.G., Kotov A.A. 2021. Bosmina longirostris (O.F. Müller, 1785) (Anomopoda: Cladocera) in Australia: a new case of the anthropogenic introduction of a boreal waterflea // Invert. Zool. Vol.18. No.3. P.240-246. doi: 10.15298/ invertzool.18.3.04

КЛЮЧЕВЫЕ СЛОВА: Bosmina, Cladocera, Австралия, фауна, биологические инвазии.

\section{Introduction}

Biological invasions are among the main recent challenges for humanity. Alien species are, unfortunately, common and widely distributed in fresh waters now (Strayer, 2010). It is well-known that some waterflea taxa (Crustacea: Branchiopoda: Cladocera) formed stable populations in non-indigenous territories after their occasional human-mediated introduction. Moreover, appearance of some alien cladocerans in new regions (e.g. Daphnia lumholtzi Sars, 1885 to North and South America, Cercopagis pengoi (Ostroumov, 1891) to North American Great Lakes), was destructive for the ecosystems and had a strong negative economic effects (Kolar et al., 1997; Laxson et al., 2003; Havens et al., 2012). At the same time, recent studies have revealed some cases of "cryptic invasions" of cladoceran non-indigenous taxa or haplotypes which have a less prominent effect and are frequently missed by hydrobiologists during routine studies, even monitoring conducting over many years (Mergeay et al., 2005; Kotov, Taylor, 2019; Taylor et al., 2020). Such cases are mainly known for the Holarctic, the region with best studied cladoceran fauna.

Some cases of such invasions are known for the Australasian region (Balvert et al., 2009; Karabanov et al., 2018; Duggan et al., 2021). Below we report on the finding of a population of Bosmina longirostris (O.F. Müller, 1785) (Anomopoda: Bosminidae) in Australia which also, most probably, has appeared as a result of occasional anthropogenic-mediated introduction.

\section{Material and methods}

A single sample was received from V.F. Matveev who collected it by plankton net and immediately fixed by $2 \%$ formaldehyde. Samples was initially examined under a stereoscopic dissecting microscope Leica MZ9.5. For morphological analysis, specimens were picked from the sample by pipettes, placed on slides in drops of glycerol, covered by cover slips and examined under a high-power microscope Olympus CX41. Four parthenogenetic were dissected for analysis of fine morphological details including the appendages. Drawings were made by camera lucida. We used terminology for morphological structures as proposed for Anomopoda by Kotov (2013).

\section{Results}

\author{
Bosmina (Bosmina) longirostris \\ (O.F. Müller, 1785) \\ Figs 1-2.
}

MATERIAL. 22 parthenogenetic females from Rainbow Lake $\left(36.376^{\circ} \mathrm{S}, 148.483^{\circ} \mathrm{E}\right)$, Kosciusko National Park, New South Wales, Australia, collected in 04.1991 by V.F. Matveev. The lake is a man-made reservoir formed when the Diggings Creek was dammed, it holds brown and rainbow trout populations (Snowy Mountain Fishing, 2021). It this locality, B. longirostris co-occurred with $B$. (Liederobosmina) meridionalis Sars, 1904.

DESCRIPTION: Parthenogenetic female. Body relatively elongated, posterior margin 


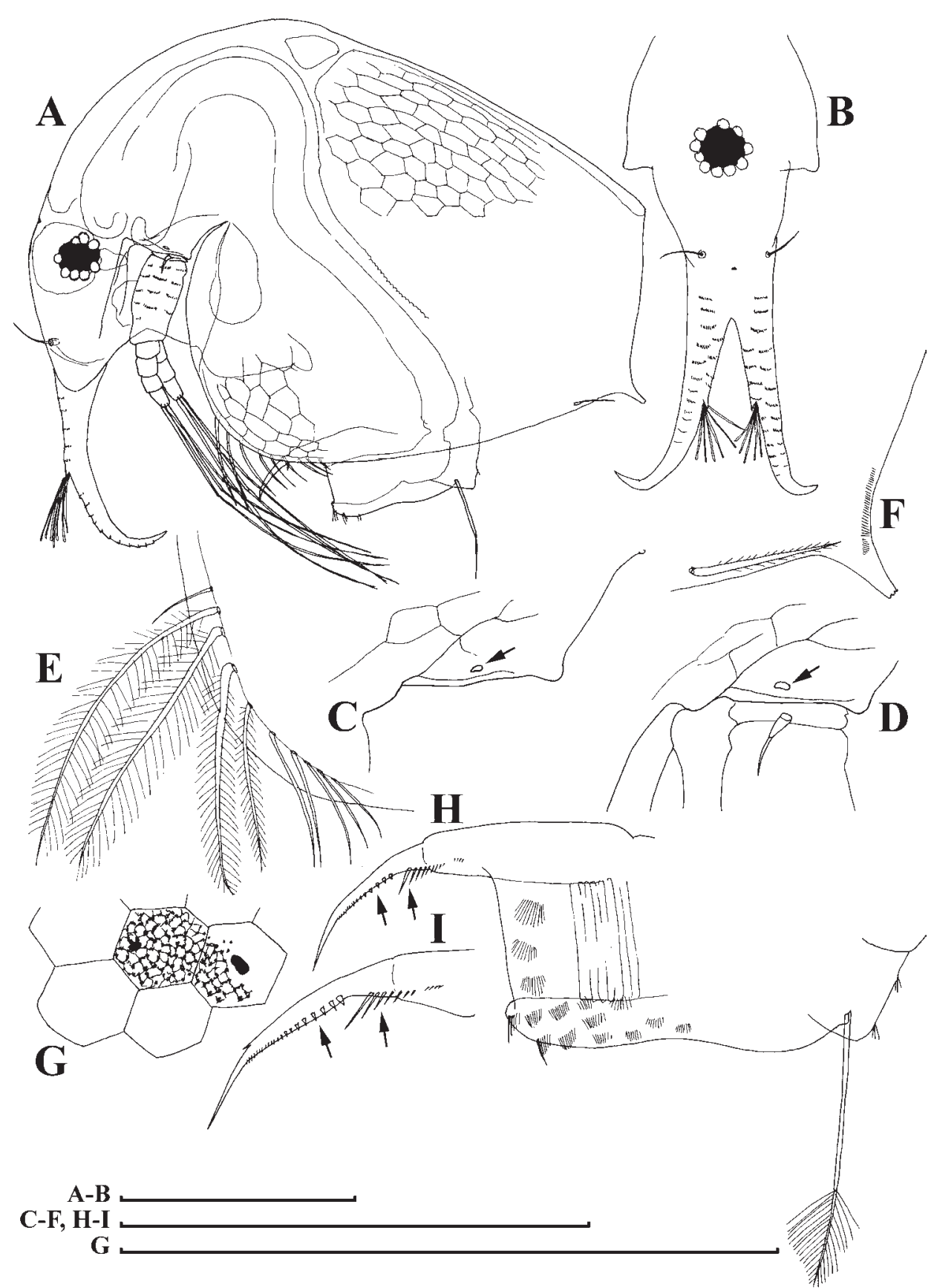

Fig. 1. Bosmina longirostris (O.F. Müller, 1785), parthenogenetic females from Rainbow Lake, Kosciusko National Park, New South Wales. A-B - lateral and anterior view; C-D - margin of head shield with lateral head pore; $\mathrm{E}$ - setae at antero-ventral angle; $\mathrm{F}$ - mucro; $\mathrm{G}$ - reticulation on valves; $\mathrm{H}-\mathrm{I}$ - postabdomen and postabdominal claw. Scale $0.1 \mathrm{~mm}$.

Рис. 1. Bosmina longirostris (O.F. Müller, 1785), партеногенетическая самка из Озера Рэйнбоу, Национальный Парк Костюшко, Новый Южный Уэльс. А-B - вид сбоку и спереди. C-D - край головного щита с латеральной головной порой. Е - щетинки на передне-брюшном крае. F - мукро. $\mathrm{G}$ - ретикуляция створки. $\mathrm{H}-\mathrm{I}$ - постабдомен и постабдоминальный коготок. Масштаб 0,1 мм. 


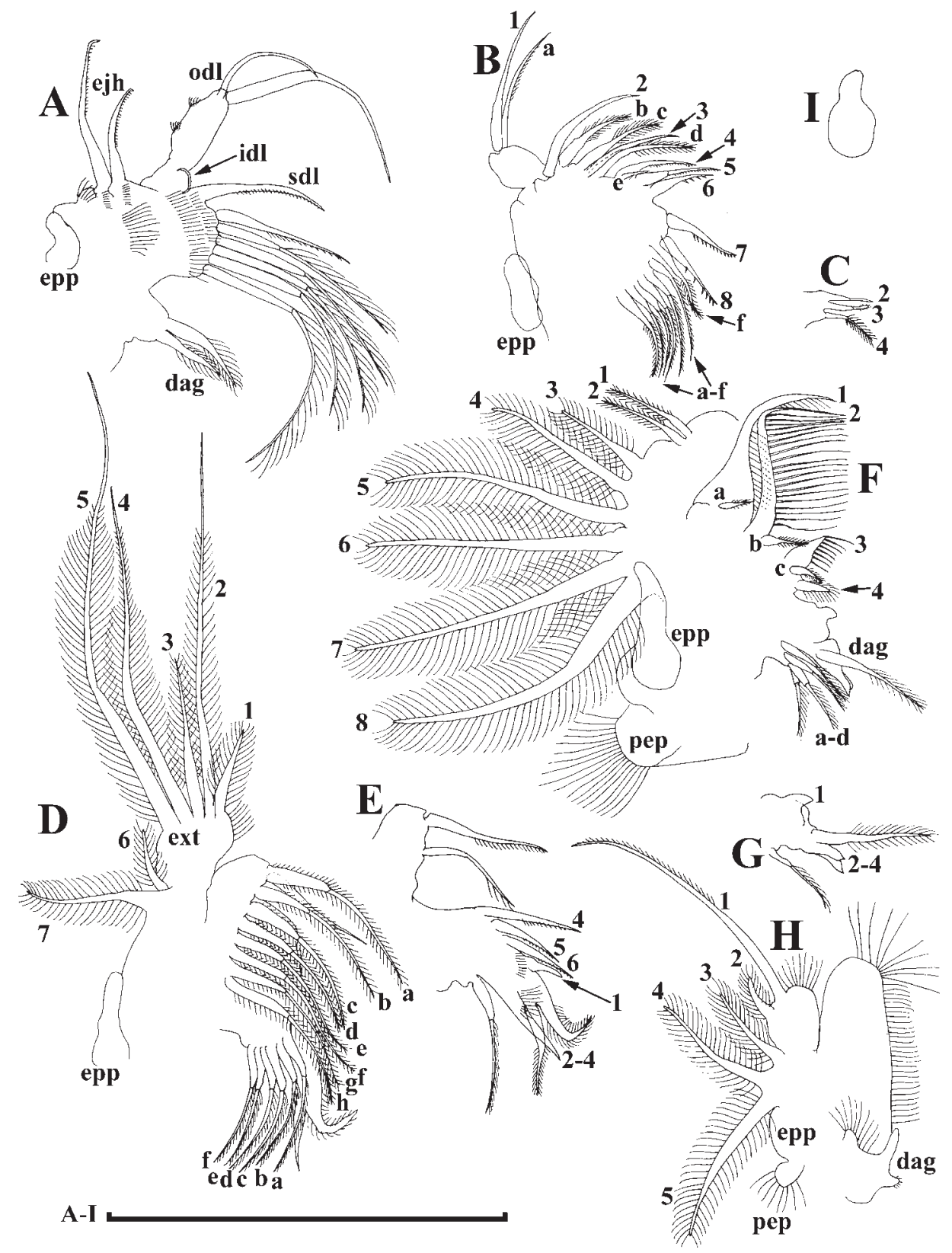

Fig. 2. Bosmina longirostris (O.F. Müller, 1785), thoracic limbs of parthenogenetic females from Rainbow Lake, Kosciusko National Park, New South Wales. A - limb I; B - limb II; C - distal armature of its gnathobase; D - limb III. E, its inner-distal portion; F - limb IV; G - distal armature of its gnathobase; $\mathrm{H}$ - limb V; I - Limb VI. Scale $0.1 \mathrm{~mm}$.

Рис. 2. Bosmina longirostris (O.F. Müller, 1785), партеногенетическая самка из Озера Рэйнбоу, Национальный Парк Костюшко, Новый Южный Уэльс. А - торакальная конечность I пары; В торакальная конечность II пары; C - дистальное вооружение гнатобазы; D - торакальная конечность III пары; Е - ее внутренняя дистальная доля; F — торакальная конечность IV пары; G дистальное вооружение ее гнатобазы; H - торакальная конечность V пары; I — торакальная конечность VI пары. Масштаб 0,1 мм. 
straight and short (Fig. 1A). Rostrum relatively long, with frontal sensory seta located far from base of antenna I, frontal head pore situated ventrally to level of sensory setae (Fig. 1B), medial pore somewhat posterior to compound eye. Lateral head pore immediately near ventral margin of fornix, in the reticulation bifurcation, postero-ventral angle of head shield somewhat projected, rounded (Fig. 1C-D). On inner face of valve, a series of long setules at anteroventral angle (Fig. 1E) and a single Kurz's seta near mucro which is short, protruding posteroventrally (Fig. 1F). Distinct polygonal reticulation on valves, there is a fine additional "net" within the polygons but it is not an external structure (Fig. 1G). Postabdomen subquadrangular, with a concave preanal margin, straight anal margin and a projection for postabdominal claws (Fig. 1H). Postabdominal claw thin, with two pectens. Distal pecten starts at $1 / 3$ of claw length as fine setules, which basally transforming into robust denticles. Basal pecten consists of 6-8 setules, decreasing in size basally (Fig. 1I). On postabdomen there is a third pecten of 4-6 small setules.

Six limb pairs as is in other species of the genus (Fig. 2).

Ephippial female, male. Not found in Australia.

Size. $0.26-0.39 \mathrm{~mm}$ in our sample.

SPECIES DIFFERENTIATION IN AUSTRALIA. B. (Bosmina) longirostris could be easily discriminated from the single indigenous Australian species of the genus, B. (Liederobosmina) meridionalis Sars, 1904 (Shiel, Dickson, 1995; Smirnov, 1995) (Fig. 3). The latter belong to the subgenus $B$. (Liederobosmina) Brtek, 1997 (replacing the name Neobosmina Lieder, 1957, as the latter subgenus was found to be a junior homonym of Neobosmina Cameron (Hymenoptera, Insecta)) and has: (1) a lateral head pore located near the mandibular articulation; (2) teeth on postabdominal claw sparsely located and strong; (3) distal half of the postabdominal claw armed by fine, short setules (Fig. 3, arrows). In B. (B.) longirostris (1) the lateral head pore is located near the head shield lateral margin (fornix); (2) the teeth on postab- dominal claw are thin and densely located; and (3) distal half of postabdominal claw armed by robust denticles decreasing in size distally (Fig. 1 , arrows). Also the females of $B$. longirostris frequently have a curved tip of antenna I (but it is not obligatory character).

\section{Discussion}

Bosmina longirostris is a new record for the Australian fauna. No differences are revealed between Australian and European B. (B.) longirostris s.str., including thoracic limbs (see Alonso, 1996). Kořínek et al. (1999) described another species of Bosmina (Bosmina) from India, B. tripurae Kořínek, Saha et Bhattacharya, 1999, which can be confused with $B$. longirostris. But B. tripurae has the lateral head pore located in middle of the reticulation bifurcation, while in $B$. longirostris this pore is located immediately near the ventral edge of head shield.

Unfortunately, we had only a formalin sample, and a genetic study was impossible. Exact mode of this population appearance is unknown, but most probably, $B$. longirostris was introduced from a Holarctic locality together with trout which is cultivated in this dam lake. The same vector was previously discussed for Chydorus sphaericus (O.F. Müller, 1776) (Anomopoda: Chydoridae) appearance in Australia (Sharma, Kotov, 2015). Indeed, many alien species of fish were intensively introduced to Australia in the past and now have a strong negative impact on the indigenous biota (Lintermans, 2004). Some invertebrates apparently were introduced together with fishes, including fish parasites (Evans, Lester 2001).

Australia was isolated from other continents for a long time, and its freshwater fauna is rich in endemics, including cladocerans, of which 103 taxa (50\%) to date are endemic (e.g. Smirnov, Timms, 1983; Frey, 1991; Shiel, Dickson, 1995; Smirnov, 1995). Several boreal cladocerans have penetrated Australia and New Zealand as a result of occasional human-mediated introduction. Some of them are rapidly replacing indigenous species in many aquatic systems (Duggan et al., 2006) and significantly 


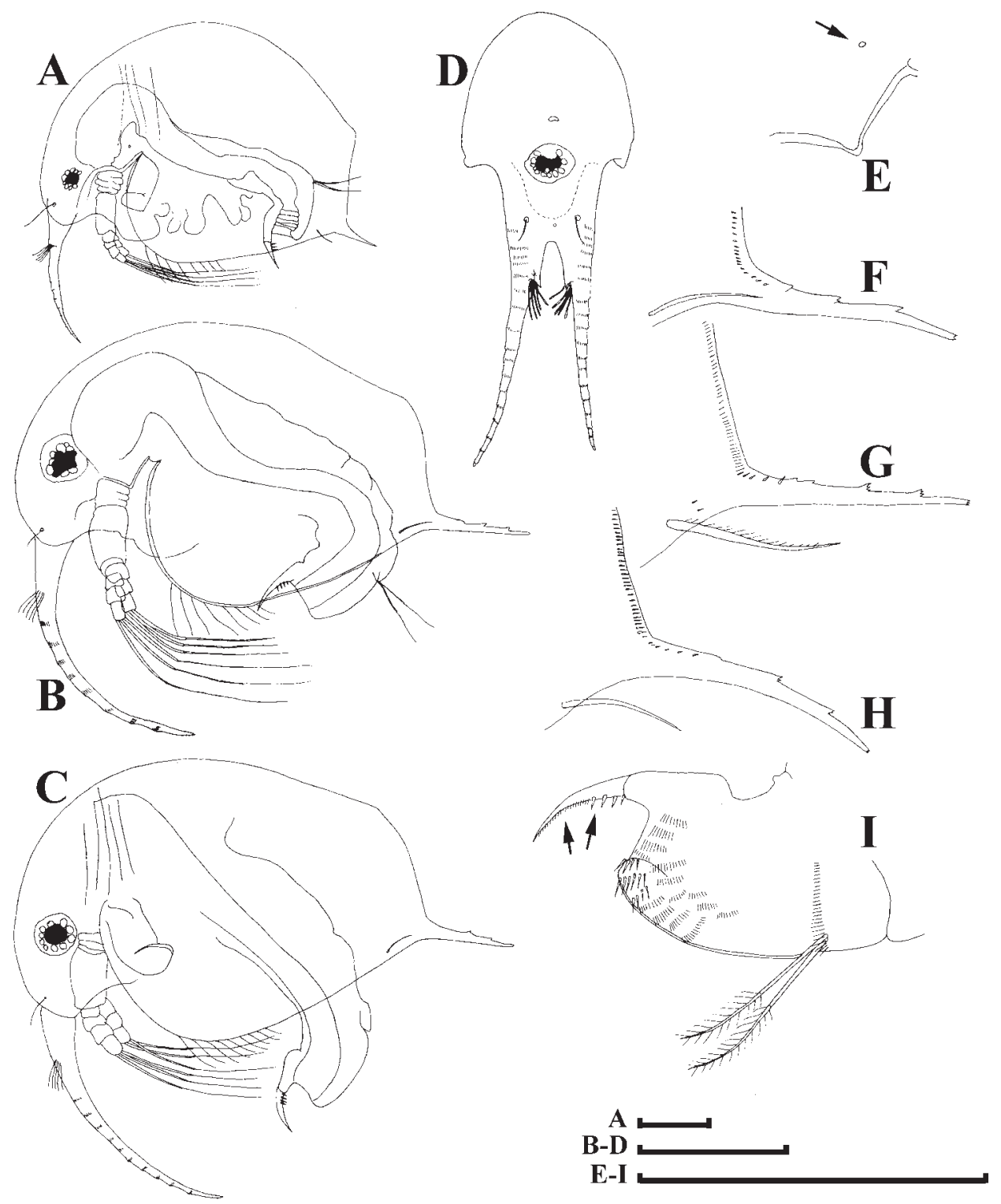

Fig. 3. Bosmina meridionalis Sars, 1904, parthenogenetic females from Rainbow Lake, Kosciusko National Park, New South Wales. A - large adult, lateral view; B-C - juveniles; D - anterior view; E - ventral margin of head shield with lateral head pore; $\mathrm{F}-\mathrm{H}$ - mucro; I - postabdomen. Scale $0.1 \mathrm{~mm}$.

Рис. 3. Bosmina meridionalis Sars, 1904, партеногенетическая самка из Озера Рэйнбоу, Национальный Парк Костюшко, Новый Южный Уэльс. А — крупная взрослая самка, вид сбоку; В-С — ювенильные самки; D - вид спереди; Е - край головного щита с латеральной головной порой; F-H - мукро; I - постабдомен. Масштаб 0,1 мм.

changing the ecosystems of some lakes (Balvert et al., 2009; Duggan et al., 2021). Effects of others is unknown to date, but they could potentially have a negative effect on freshwater eco- systems (Duggan et al., 2012; Sharma, Kotov, 2015; Karabanov et al., 2018). Bosmina longirostris described in the present publication is among such taxa. 
Our short communication demonstrates that studies of Australian zooplankton need to be intensified as new non-indigenous species with unclear effects are being introduced to this continent recently, but only Daphnia is under intensive study.

\section{Compliance with ethical standards}

CONFLICTS OF INTEREST: The authors declare that they have no conflicts of interest.

Acknowledgements. This communication is dedicated to the 70th anniversary of Professor V.V. Malakhov, Head of the Department of Invertebrate Zoology of M.V. Lomonosov Moscow State University, teacher of both authors.

We are very grateful to V.F. Matveev for the sample, T. Greville for the information on the lake and to R.J. Shiel for critical and linguistic comments on earlier draft.

The study is conducted in the frames of a grant from the President of the Russian Federation to young Ph.D. researchers (MK-525.2020.4 for $P G)$.

\section{References}

Alonso M. 1996. Crustacea Branchiopoda // Fauna Iberica. Vol.7. Museo Nacional de Ciencias Naturales. Madrid: Consejo Superior de Investigaciones Cientificas. $486 \mathrm{pp}$.

Balvert S.F., Duggan I.C., Hogg I.D. 2009. Zooplankton seasonal dynamics in a recently filled mine pit lake: the effect of nonindigenous Daphnia establishment // Aquatic Ecology. Vol.43. P.403-413. http://dx.doi. org/10.1007/s10452-008-9165-Z

Duggan I.C., Green J.D., Burger D.F. 2006. First New Zealand records of three non-indigenous zooplankton species: Skistodiaptomus pallidus, Sinodiaptomus valkanovi, and Daphnia dentifera // New Zealand Journal of Marine and Freshwater Research. Vol.40. P.561569.

Duggan I.C., Özkundakci D., David B.O. 2021. Longterm zooplankton composition data reveal impacts of invasions on community composition in the Waikato lakes, New Zealand // Aquatic Ecology. On-line: https://doi.org/10.1007/s10452-020-09803-8.

Duggan I.C., Robinson K.V., Burns C.W., Banks J.C., Hogg I.D. 2012. Identifying invertebrate invasions using morphological and molecular analyses: North American Daphnia 'pulex' in New Zealand fresh waters // Aquatic Invasions. Vol.7. P.585-590.

Evans B.B., Lester R.J. 2001. Parasites of ornamental fish imported into Australia // Bulletin-European Association of Fish Pathologists. Vol.21. P.51-55.

Frey D.G. 1991. The species of Pleuroxus and of three related genera (Anomopoda, Chydoridae) in southern
Australia and New Zealand // Records of the Australian Museum. Vol.43. P.241-274.

Havens K.E., Beaver J.R., East T.L., Work K., Phlips E.J., Cichra M.F., Croteau A.C., Rodusky A.J., Fulton R.S., Rosati T.C. 2012. The outcome of the invasion of Florida lakes by Daphnia lumholtzi // Freshwater Biology. Vol.57. P.552-562.

Karabanov D.P., Bekker E.I., Shiel R.J., Kotov A.A. 2018. Invasion of a Holarctic planktonic cladoceran Daphnia galeata Sars (Crustacea: Cladocera) in the Lower Lakes of South Australia // Zootaxa. Vol.4402. P.136-148.

Kolar C.S., Boase J.C., Clapp D.F., Wahl D.H. 1997. Potential effect of invasion by an exotic zooplankter, Daphnia lumholtzi // Journal of Freshwater Ecology. Vol.12. P.521-530.

Kořínek V., Saha R.K., Bhattacharya T. 1999. A new member of the subgenus Sinobosmina Lieder, 1957: Bosmina tripurae sp. n. (Crustacea, Cladocera) from South Asia // Hydrobiologia. Vol.392. P.241-247.

Kotov A.A., 2013. [Morphology and phylogeny of the Anomopoda (Crustacea: Cladocera)]. Moscow: KMK Press. 638 pp. [In Russian]

Kotov A.A., Taylor D.J. 2019. Contrasting endemism in pond-dwelling cyclic parthenogens: the Daphnia curvirostris species group (Crustacea: Cladocera) // Scientific Reports. Vol.9. Art.6812. https://doi.org/ 10.1038/s41598-019-43281-9.

Laxson C.L., McPhedran K.N., Makarewicz J.C., Telesh I.V., Macisaac H.J. 2003. Effects of the non-indigenous cladoceran Cercopagis pengoi on the lower food web of Lake Ontario // Freshwater Biology. Vol.48. P.2094-2106.

Lintermans M. 2004. Human-assisted dispersal of alien freshwater fish in Australia // New Zealand Journal of Marine and Freshwater Research. Vol.38. P.481-501.

Mergeay J., Verschuren D., De Meester L. 2005. Cryptic invasion and dispersal of an American Daphnia in East Africa // Limnology and Oceanography. Vol.50. P.1278-1283.

Sharma P., Kotov A.A. 2015. Establishing of Chydorus sphaericus (O.F. Müller) s. str. (Crustacea: Cladocera) in Australia: consequences of mass fish stock from Northern Europe? // Journal of Limnology. Vol.74. P.225-233.

Shiel R.J., Dickson J.A. 1995. Cladocera recorded from Australia // Transactions of the Royal Society of South Australia. Vol.119. P.29-40.

Smirnov N.N. 1995. Check-list of the Australian Cladocera (Crustacea) // Arthropoda Selecta. Vol.4. No.1. P.3-6.

Smirnov N.N., Timms B.V. 1983. A revision of the Australian Cladocera (Crustacea) // Records of the Australian Museum, Supplement. Vol.1. P.1-132.

Snowy Mountain Fishing. 2021. https://www. snowymountainsfishing.com.au/region/lakes/rainbow-lake/

Strayer D.L. 2010. Alien species in fresh waters: ecological effects, interactions with other stressors, and prospects for the future // Freshwater Biology. Vol.55. P.152-174.

Taylor D.J., Connolly S.J., Kotov A.A. 2020. The intercontinental phylogeography of neustonic daphniids // Scientific Reports. Vol.10. Art.1818.

Responsible editor A.Yu. Sinev 